\title{
Transatlantica
}

Revue d'études américaines. American Studies Journal

\section{Interview with Alison Bechdel about her presentation of Fun Home in Paris and Tours}

\section{Anne Crémieux}

\section{(2) OpenEdition}

1 Journals

\section{Electronic version}

URL: http://journals.openedition.org/transatlantica/1220

DOI: 10.4000/transatlantica.1220

ISSN: $1765-2766$

Publisher

AFEA

\section{Electronic reference}

Anne Crémieux, "Interview with Alison Bechdel about her presentation of Fun Home in Paris and Tours", Transatlantica [Online], 1 | 2007, Online since 08 July 2013, connection on 29 April 2021. URL: http://journals.openedition.org/transatlantica/1220 ; DOl: https://doi.org/10.4000/transatlantica.1220

This text was automatically generated on 29 April 2021

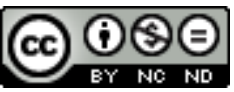

Transatlantica - Revue d'études américaines est mis à disposition selon les termes de la licence Creative Commons Attribution - Pas d'Utilisation Commerciale - Pas de Modification 4.0 International. 


\section{Interview with Alison Bechdel about her presentation of Fun Home in Paris and Tours}

Anne Crémieux

\section{AUTHOR'S NOTE}

http://dykestowatchoutfor.com/alison-bechdel 


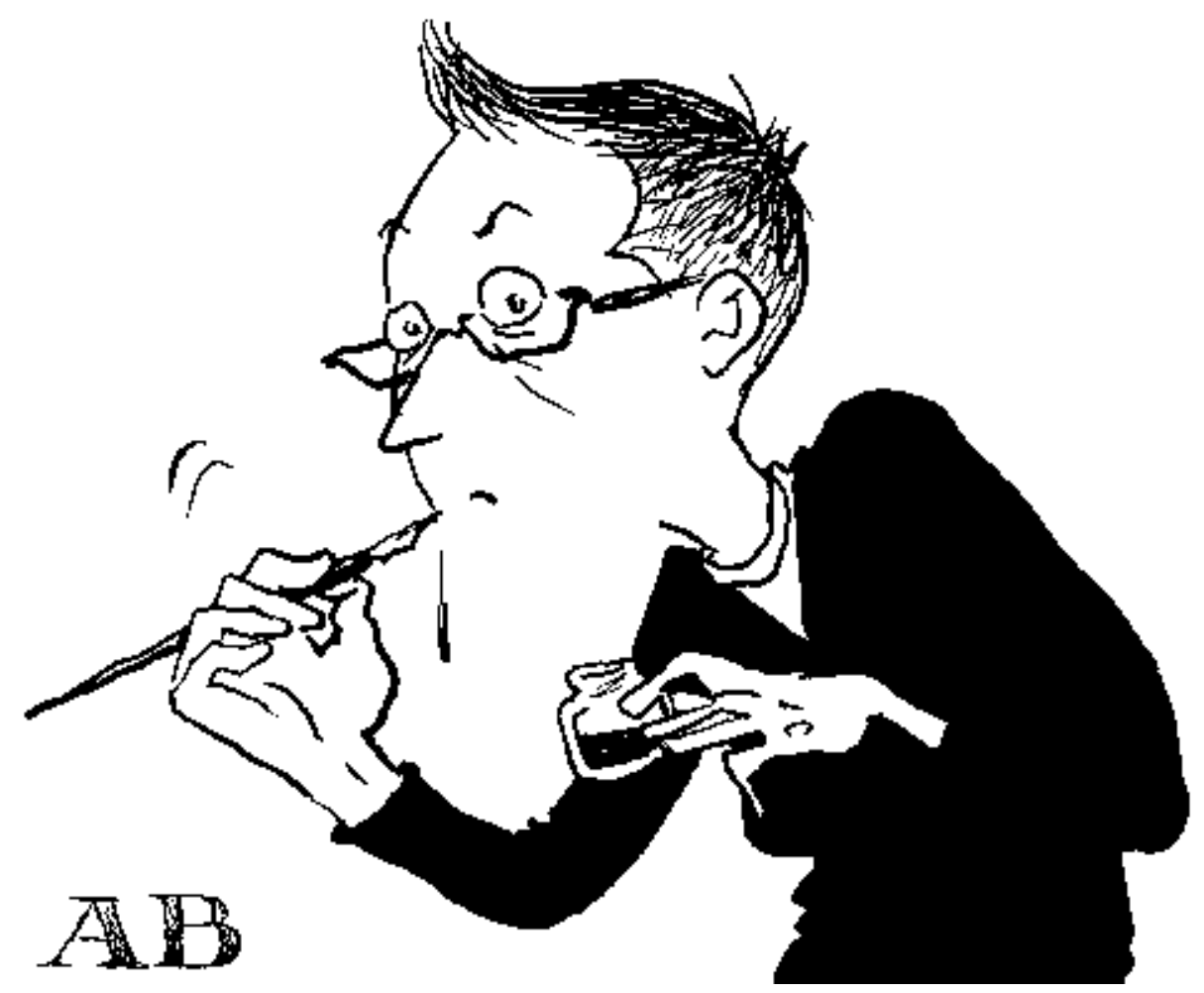

“SELF-PORTRAIT BY ALISON BECHDEL," COURTESY OF THE AUTHOR

TRANSAT: How has Fun Home's reception been different in nature from the reactions to Dykes to Watch Out For?

Alison Bechdel: Fun Home has had a very different reception than Dykes to Watch Out For. It's a very different type of book. I don't want to downplay DTWOF-I'm very proud of the series, and I think it's been a worthy contribution to queer culture as well as to the comics genre. But Fun Home was a real creative leap for me. Creative leaps don't always work out, and aren't always recognized. So I feel very fortunate that this book got the critical attention that it did. I think good timing was part of it. Graphic narrative has been getting closer and closer to acceptance as a legitimate literary form for a couple decades now, and I was able to ride that wave.

T: Having now presented your work in Europe, what are your general impressions of your public over here-whether of the feminist community, or the greater public? Do European reactions differ from North-American reactions?

AB: I've mostly spent any time in the UK and France-and very little at that. But in terms of lesbian culture, I had the sense that both countries are where the US was maybe ten years ago. There's still a vibrancy and sense of community and political purpose that has long since faded from the American scene.

I didn't know much about the European comics scene until my recent trips to France. I was pretty blown away by how rich the graphic narrative tradition is, and how avid its readership is. France seems way ahead of the US in that regard. But the UK seems behind the US. I got the sense that comics haven't quite gotten a foothold there yet.

T: Why do you choose to focus your presentations at book signings on the technique of drawing (which is fascinating) rather than the content of your books? We were struck by how open you were about the obsessive nature of the work that went into the creation of 
Fun Home. Why has it been important for you to talk about it, or why is it important to you that your readers know about that aspect?

AB: Normally at my presentations, I read from my work before talking about the technique. But it didn't make sense to do that when I can't speak French, and my audience might not be fluent in English. Also, my editor told me that French authors don't typically read from their work at book signings. So in France, I focused on the technical aspects of the work because it was easy to do that without worrying too much about the translation problem. Graphic novels have a physical reality in a way that a prose book doesn't.

I was intimately involved for years in the physical creation of Fun Home. Not just writing but designing and then drawing-manually laboring over-each page. Talking about this physical process seems as relevant to me as talking about the content of the book. Particularly since part of the content deals with my obsessive-compulsive nature! It's not so much that I'm compelled to tell readers about my obsessiveness. Just that if I'm going to talk at all about how I made the book, the obsessive aspect is unavoidable.

T: Do you sometimes feel misunderstood about certain aspects of your work?

AB: Oh, I always feel misunderstood by someone about something. But I'm feeling much less bitter nowadays. Getting a little mainstream success goes a surprisingly long way in that regard.

T: How do you feel about your book being the subject of academic work? What is it like to listen to people analyze your book in front of you?

AB: I feel very honored to have my book analyzed academically. I guess I also feel a little foolish, too-but I understand that it's not personal. Once you put a book out into the world, it becomes the property of the world. So if I'm listening to an academic deconstruct my family, I'm able to hear it somewhat dispassionately, as if it's about a family in a book.

INDEX

Subjects: Trans'Arts 